Journal

of Geography

Politics and Society

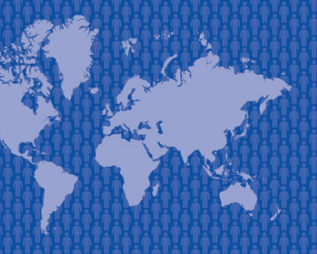

$8(1) / 2018$

\section{Journal of Geography, Politics and Society}

$2018,8(1), 56-63$

DOI 10.4467/24512249JG.18.007.8159

\title{
TECHNOLOGY MEDIATION AS AN EFFECTIVE PROCEDURE OF PUBLIC ADMINISTRATION IN SOCIAL PROTECTION OF ANTITERRORIST OPERATIONS PARTICIPANTS
}

\author{
lurii Zhogno \\ Department of Public Management, National Academy for Public Administration under the President of Ukraine, Ezhen Pottier 20, Kyiv, Ukraine, \\ e-mail: zhuyrii@gmail.com
}

\section{Citation}

Zhogno I., 2018, Technology mediation as an effective procedure of public administration in social protection of antiterrorist operations participants, Journal of Geography, Politics and Society, 8(1), 56-63.

\begin{abstract}
This article discusses the efficiency of the technology as mediation procedures of public administration in the social protection of members of the anti-terrorist operation (ATO) and their families. The author introduced empirical research, study results which allowed the present three-factor model of efficiency mediation. The validity of the model is confirmed using standardized statistical criteria. Empirically found that the effectiveness of technology mediation procedures as public administration correlated, both individual and social characteristics combatant of ATO and communicative competence of public servants involved in the process of mediation.
\end{abstract}

\section{Key words}

Ukraine, public administration, mediation, member of the anti-terrorist operation, social injuries.

\section{Introduction}

Ukrainian state and society are at a new stage of deep changes, which affect the condition of the society, the major spheres of life and for each individual person (Горбулін, 2016). The present Ukraine is marked by aggression of Russia and the severe consequences of military conflict (Гай-Нижник, 2017): internal migration (about 1.5 million internally displaced persons), socio-economic, political tensions and social disadaptation, the mobilization of the army (about 100 thousand people mobilized) heavy casualties (over 10 thousand persons' military and civilian dead) and unmet need for rehabilitation and re-socialization of thousands of wounded and disabled veterans, participants in anti-terrorist operations (ATO).

Post-revolutionary Ukrainian government has failed a test not only on the ability to effectively counter the Russian force pressure, the ability to actually start and promote systemic reform, but also on the ability to provide European choice of Ukraine is primarily the development of an optimal model of foreign policy which are guarantees national security and domestic policies that would ensured adequate social welfare standards to needy categories of the 
population, which in the first place, are victims by armed Russian aggression. From the spring of 2015 in Ukraine formed a new, according to the theory of social space P. Bourdieu (Бурдье, 2007), "actually operating group of people", which act as autonomous actors in a multidimensional social fields. Detailed explication of this social field reveals at least several vectors of social policy is still not settled in the Ukrainian society: the social and economic welfare, employment, health care with extensive rehabilitation component, integration of internal migrants, and, most importantly, the reintegration of ATO's combatants and members of their families. These groups are situational and at the legislative level are differentially conditional on subgroups of social agents:

- military subgroup - combatants (military personnel and volunteers involved in the fighting and the ATO), ATO veterans and people with disabilities, members of ATO and their families;

- migrant subgroup - is internally displaced persons, including those who need social protection of the disabled, the unemployed, pensioners and the others.

Therefore, in the modern social life of Ukrainian society actually latest social topology is objectified (including the above group of social agents with the appropriate set of operating status, characteristics, needs, opportunities, etc.) that the military reality of Ukraine. In the author's concept of P. Bourdieu (Бурдье, 2007), agent capital in the social space is defined by its position on the various dimensions of this space - economic, cultural, legal and etc. Certain types of social capital determine the patterns of social interaction at this dimension of social space ("rules of the game") and "chances to win" of a particular social agent in this interaction (the probability of satisfaction of own needs).

It should also be noted that the explication of Ukrainian realities today it distinguishes characteristic feature - the "existence of conditions and actions for social injury" (Решетніченко et al., 2012, p. 37), as a result of layers of social, physical and psychological trauma individual and collective quality of regional social field. It is also clear that the chances of winning the above populations is not currently high and, not least, depending on the mechanism involved public administration and competencies of civil servants.

Civil servants are an important subject of public administration and relevant state social policy, as you know, helps optimize the use of resources of different countries to pursue national interests and ensure effective dialogue of citizens and public officials, which includes differentiated and balanced approach to meet the needs of social vulnerable groups (Білинська, 2013). In this context there is a need for purposeful formation of certain competencies of civil servants, including and the ability to adequately respond to conflicts in the interaction of social groups (the conflict or communicative competence). This civil servant must effectively settle conflicts relevant to broadcast social and cultural values have negotiation skills and business communication, and exchange of basic social values and communication with mass addresser.

Conflictogenes of new social reality continues to be produced through permanent military confrontation in the east of Ukraine and it induced social tension that creates some social challenges and problematic situations (Решетніченко et al., 2012). Social policy, as the activity of state regulation of socio-economic conditions of society to the welfare of its members, eliminate the negative effects of maladaptive functioning processes for social and political stability in the country confronts public service related goals and objectives. As the main objectives of social policy is to provide every citizen effective medium that allows him to work for the welfare of the family and strengthen targeted social assistance to vulnerable groups of the population with low income (Головатий, 2005), and relevant goals of social policy at the present stage of socio-economic development of Ukraine is to implement comprehensive measures of social security settlers and ATO's combatants, particularly in the areas of social protection and employment, palliative care, health and social services, increase social guarantees for families with children and persons with disabilities.

The relevance of these objectives is increasing because of the increasing social polarization, mind blowing falling living standards and income levels differentiated by different groups; crisis spiritual sphere of society - deformation value sphere of individual and collective consciousness that produces the crisis of social identity; total social instability and a high level of conflict within the social structure of Ukrainian society; growth of criminal activity and suicide (Решетніченко et al., 2012). As a result, according to experts, a characteristic feature of Ukrainian reality is «the existence of conditions and actions for social injuries».

After the demonstration psychosomatic phenomenon of maladjustment components, usually caused its social component with the appropriate set of problems produced around ATO's combatant. The complex of such potentially problematic situations that represent a group of ATO's combatants locally suffer and the system of public administration in the social sphere of Ukraine's regions are involved in active measures ATO, particularly in the Odesa region. Despite the obvious processing and seriousness of 


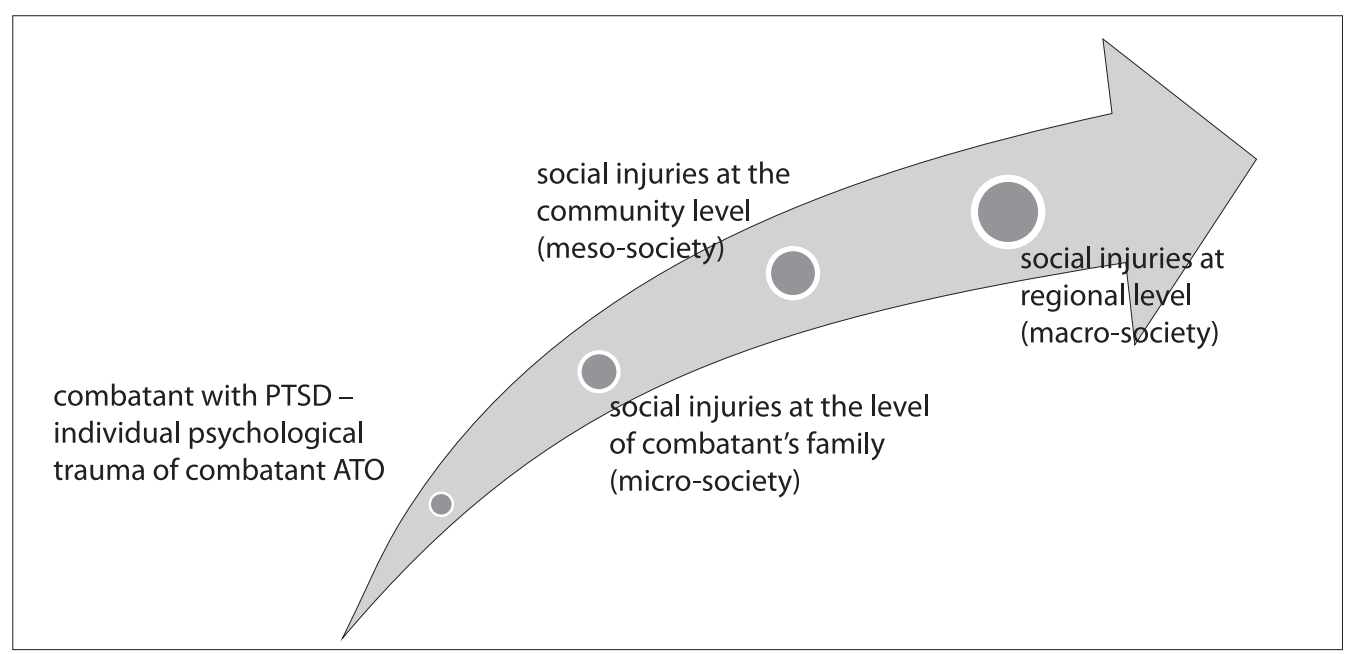

Fig. 1. Genesis of social injuries in the region

Source: own study.

the problem of social exclusion, it remains understudied and is still relevant for Ukraine. Therefore, we believe that social genesis of trauma to the military subgroups social agents in the Odessa region develops in the following way (Fig. 1).

The upward trend of social injuries has obviously some related factors of different quality, one of which reproduces the communication features of interaction of social agents in the region in terms of ATO. This mechanism of regional public administration and communication as the plane of its implementation, have a direct impact on the factors produced by the process of social injuries. It seems that the use of innovative technologies in the practice of regional public administration in conditions of social injuries, in fact, is a problematic situation of our study. The theoretical construct "communication social injuries - public administration", in this case, appears to the researcher as implicit functional dependency that requires some explication.

The main aim of our research is a experimental study efficient use of mediation as a procedure of public administration in the field of social protection of ATO's combatants, which is of considerable practical importance for the implementation of highly effective public administration at the regional level. The object of our study is the process of public administration social issues ATO's combatants. The subject of the study, respectively, is the effectiveness of technology mediation procedures as public administration in social security ATO combatants and their families. The main methods of study were: content analysis of professional literature, field experiment and statistical analysis of the results by the experiment methods of mathematical statistics (Z-criterion Kolmogorov-Smirnov, U-Mann-Whitney criterion for two independent samples, factor analysis).
Purposeful mechanism of public administration in social security management system is carried out, which includes government, local governments, political parties, NGOs, etc. Public administration social sphere in the context of post-revolutionary Ukraine should be a mechanism, based primarily on European imperatives that determine the real quality of life, social welfare, employment, social support, mitigating the negative effects of individual and social inequality, social and economic tensions in society (Скуратівський et al., 2007).

At the same time, it is clear that Ukraine can avoid the influence of factors of globalization, so there is the need to apply modern scientific approaches to adapt to the specifics of globalization and development of scientifically based recommendations for public administration of various spheres of society in the context of globalization and military aggression. According to the civilizational paradigm, Ukraine, as a country on the border of Western and Eastern civilizations, will not escape the relevant civilizational choice. It refers to the evolutionary paradigm of standards and highly international community, including the principles and methods of effective public administration.

These standards, in addition to political, include economic, technological, environmental and communication standards, including technology mediation as a method of pre constructive resolution of conflicts involving a neutral third party (Редлих, Миронов, 2009). Today, technology mediation in Ukraine is not institutionalized (03.11.2016, Parliament of Ukraine adopted "Law on Mediation" only in the first reading), which allows free use of a relatively wide range of social agents.

It should be noted that the problem of re-socialization of ATO's combatants is extremely important 
for civil servants and local government because of its potential threat to the stability of social welfare in the region, diversity and novelty. Despite the large number of scientific publications and studies on the social and psychological rehabilitation of combatants of armed conflict still unresolved pressing issues of socio-economic, medical, social and psychological support ATO's combatants who faced with a total vacuum in the field of socio-economic needs. In particular, the study of domestic and foreign experts indicate significant number of combatants (according to different estimates $7-10 \%$ in general) with the worst version of combat the effects of stress, which manifests complex psychosomatic symptoms, including stress disorders - PTSD, etc. (Ursano et al., 2010). This includes psychosocial features combatant experiencing combat stress, particularly during resocialization, actually, when and produced symptoms of maladjustment and social injuries of micro-, meso- and macro levels (see Fig. 1).

Today, there are a few basic scientific concepts, experiences combatant on trauma and its social and existential aspects and biological factors of development. PTSD, according to researchers, is a complex phenomenon involving symptoms of hyper-arousal, intrusive experiences of traumatic events, dissociation, anger / aggression, disruption of information processing / memory disorders, anxiety / panic, etc. (Ursano et al., 2010). Obviously, if this state of the processes of communication and social interaction combatants have the potential complications and the likelihood of injury increases social induction that would attract the attention of public administration, as well as mediators and researchers.

In the context of re-socialization of combatants and the reduction of social injuries in the region particularly important to establish effective communication with the public servant ATO's combatant and members of his family at all stages of re-socialization, including:

1. During treatment and rehabilitation - by increas-

ing awareness ATO's combatant psychosocial impact of traumatic events and active adaptive overcome the influence of medication and cognitive behavioral therapy (How to..., 2008), optimize compliance with treatment and rehabilitation team, hospital, government representatives, etc.

2. During resocialization - conducting psycho-education and motivational measures moderation ATO's combatant compliance with rehabilitation team.

3. At all stages of re-socialization - monitoring the quality of the process of socialization ATO's combatant and his family using social-psychological technologies (the psychosocial and legal support, the mediation / moderation, etc.); study the effectiveness of using technology as mediation procedures of public administration in the social protection of ATO's combatants.

\section{The results of the experiment}

Our message highlights the results of the social project of the NGO "ELEOS" in the social project "Palliative care seriously ill ATO's combatants at home in the post-hospital period", which was introduced in 2015 under the "Programs solving priority social problems of the city with the use of social order", in particular, joint mediators of the NGO "ELEOS", civil servants of the municipality of Odessa (Department of labor and social assistance) and the Military Commissariat of Odessa region. At the time of this project the specialists of the NGO "ELEOS" made a number of social events such as:

- distance and group psychosocial and legal counseling ATO's combatants and their families;

- social, mediation, legal and psychological assistance to ATO's combatants and their families at home and on the request;

- monitoring and evaluation: individual request of ATO's combatants and their families, their social capital (family, social support groups, etc.), typology and dynamics of resolving social difficulties ATO's combatants need to involve local authorities, the conflict combatant audit request and the need for specific social, psychological and legal services, including legal aid and mediation.

The main pool problem situations on the stages of treatment, rehabilitation and re-socialization of ATO's combatants shown in Fig. 2.

Main field experiment sample $(\mathrm{n} 1=78)$ mainly homogeneous: all 78 combatants - males, all are members of ATO, all combatants are military status ranks or junior officers, middle age: $35.7 \pm 11.2$ years. The experiment also included requests for mediation received from family members of ATO's combatants $(\mathrm{n} 2=112)$. Based on clinical and psychopathological research method ATO mental state combatants, with the main medical diagnosis, it was found that all of them have symptoms severe reactions to stress and adaptation disorders (code F43 according to ICD-10 (International..., 2016)). Thus, the study sample is representative enough as gender, age, medical diagnosis and the military status of ATO's combatants.

It should be noted that the active use of social and psychological activities in our project, including: psychosocial intervention in the process of resocialization of the consultants and the number of 
ensure the ATO's housing and land

execution of social assistance (benefits or payments) on the ATO's status or veteran, families enjoying an design / renovation wages for military charter design / renovation of social assistance for health establishing the status of disabled veterans establishing medical diagnosis combatant establishing military status by ATO or fighting recover lost documents combatant recovery of adequate response of public administration

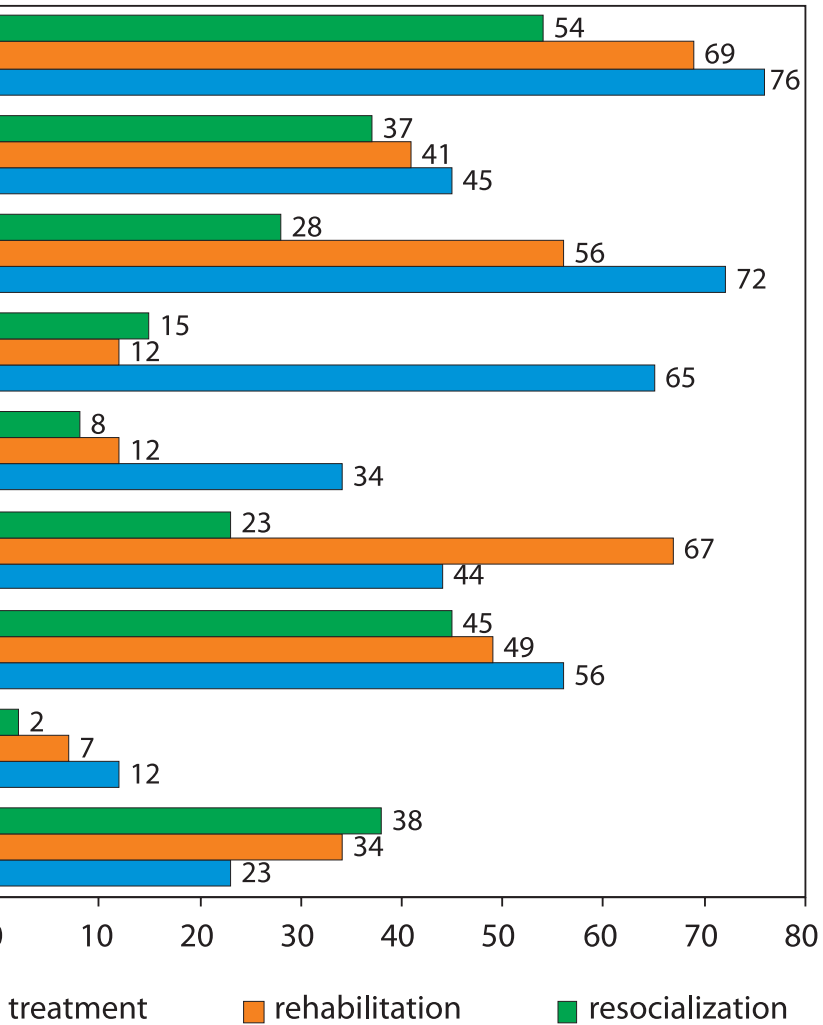

Fig. 2. Pool problematic situations on the stages of treatment, rehabilitation and re-socialization of ATO's combatants $(n=78)$

Source: own study.

The number of cases requiring consulting services / mediation / legal aid

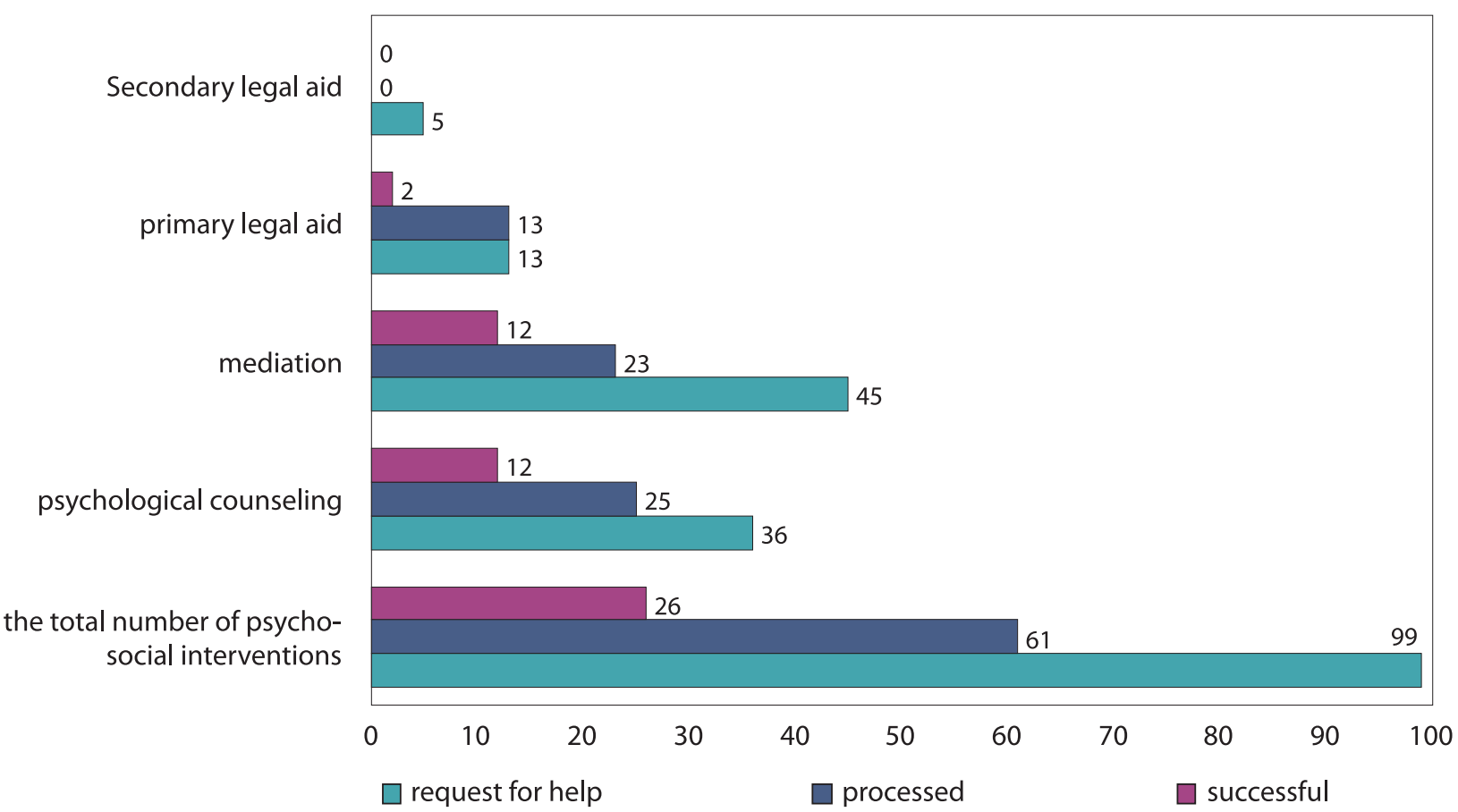

Fig. 3. Socio-psychological technologies of social project of NGO "ELEOS" Source: own study. 
cases that were processed by consulting / mediation / legal aid - corresponded to the level of social tension in the target group (Fig. 3).

Subsample (subgroups) field experiment made experimental group ( $\mathrm{n} 3=23)$ - cases using mediation and control group ( $n 4=45$ ) - cases without using a mediation procedure. A preliminary statistical analysis of the study Z-sided Kolmogorov-Smirnov criterion testified $(\rho \leq 0.001)$, all variables that describe the overall sample is nonparametric. These two subgroups, which are separated by the criterion "use of technology mediation" checked for authenticity differences results through U-Mann-Whitney for 2 independent subsamples that confirming their homogeneity. This criterion has found reliable differences between them $(\rho \leq 0.05)$ with only 2 interchangeable field experiment:

- motivation ATO's combatants family on request for mediation, $\mathrm{U}=617.4$;

- duration of the previous process of resocialization, including treatment and rehabilitation, $\mathrm{U}=222.0$.

In addition, to reduce the variables of the experiment we conducted factor analysis procedure for experimental subgroups, which helped make the next 3-factor model (Tab. 1)

\section{Discussion of results}

It seems necessary to initiate such preliminary generalizations about the estimated 3-factor model efficiency technologies as mediation procedures of public administration in the social protection of ATO's combatants:

- accumulated percentage of the total variance of model constructed $(74.94 \%$ of the total variance results of subgroup), mentioned criteria sampling adequacy Kaiser-Meyer-Olkin and Bartlett sphericity samples allow collectively implement meaningful interpretation of the results of factor analysis of subgroups for the purpose of research; - model is sufficiently differentiated, since almost all variables factorization procedure (indicators characterizing subgroup) grouped according to the fate of variance due to the influence of certain factors;

- model is polarized, while the positive pole Vulnerable: performance indicator mediation, char-

Tab. 1. Matrix factors weighting coefficients models $(n 3=23)$

\begin{tabular}{|c|c|c|c|}
\hline \multirow{2}{*}{ Replacement procedure factorization } & \multicolumn{3}{|c|}{ Factors Model } \\
\hline & 1 & 2 & 3 \\
\hline motivation in family ATO's combatant to request mediation & & 0.255 & \\
\hline level of socio-economic well-ATO's combatant (economic status) & & & 0.318 \\
\hline $\begin{array}{l}\text { the duration of the previous re-socialization process (including treatment } \\
\text { and rehabilitation) }\end{array}$ & 0.199 & & \\
\hline level of psychosomatic disorders combatant (medical diagnosis) & & & -0.315 \\
\hline category conflict in continuum „,social-criminal” ** & -0.172 & & \\
\hline category (A. B. C) a public servant. that is a party to the conflict & -0.120 & & \\
\hline the success of the mediation procedure & & 0.264 & \\
\hline resocialization combatant phase (treatment. rehabilitation. re-socialization) & & & -0.230 \\
\hline category (A. B. C) a public servant - co-mediator & & & 0.166 \\
\hline ATO combatant motivation to request a mediation & & 0.152 & \\
\hline compliance level civil servants mediator & & 0.297 & \\
\hline communicative competence level civil servant (peer review) & & 0.329 & \\
\hline conclusion of mediation agreement (duration. costs pre- mediation) & & -0.306 & \\
\hline the duration of the mediation procedure & 0.290 & & \\
\hline readiness to innovate public servant - co-mediator (peer review) & 0.334 & & \\
\hline percentage of the total variance factor.\% & 33.98 & 22.45 & 18.51 \\
\hline the accumulated percentage of the total variance.\% & 33.98 & 56.43 & 74.94 \\
\hline \multicolumn{4}{|l|}{$\begin{array}{l}\text { method of extraction factors - Principal Component Analysis } \\
\text { method rotation factors - Varimax with Kaiser Normalization } \\
\text { criterion sampling adequacy Kaiser-Meyer-Olkin. } k=0.444 \\
\text { sphericity criterion sampling Bartlett. } s=248.13(\rho \geq 0.001)\end{array}$} \\
\hline
\end{tabular}

Notes: * - data derived from expert assessment of experts of consultant NGO "ELEOS"; ** - see explanation in Fig. 2. Source: own study. 
acteristics of the mediation procedure, professional quality of public servant (in the case where he is involved as a co-mediator) and motivational characteristics combatant ATO; at the opposite pole in the reciprocal ratio found themselves: the level of physical and neuropsychiatric disorders of ATO's combatants (medical diagnosis), the fact of the presence of combatants in the early stages of re-socialization, character themes of conflict and the fact that the presence of a civil servant in the conflict.

Thus, the model efficiency technologies as mediation procedures of public administration in the social protection of combatants ATO has 3 factors, including:

- Factor №1 "co-mediation" (holds 33.98\% of the total variance subsample) - reflects the peculiarities of public administration using technology mediation, which involved a public servant as co-mediator; factor focuses on the correlation length of the mediation procedure with the duration of the previous process of re-socialization, communication and reciprocal closeness to the criminal status of the conflict and the presence of a civil servant in the conflict;

- Factor №2 "efficiency mediation" (holds $22.45 \%$ of the total variance subsample) - plays connection efficiency mediation procedure with the level of motivation of combatants to participate in mediation, the level of compliance with the mediator civil servant at the time of mediation; not least proved successful mediation correlation with the level of communicative competence of a civil servant and reciprocal relationship with the duration of the initial stages of mediation;

- Factor №3 "features of combatant" (holds 18.51\% of the total variance subsample) - plays the reciprocal relationship of psychosomatic disorders combatant ATO and its location on the route resocialization of its economic status as well as the practical experience of civil servant - co-mediator.

\section{Discussion of results and conclusions}

During the process the results of empirical research presented factor model of efficiency technologies as mediation procedures of public administration in the social protection of ATO's combatants. The validity of the model is confirmed using standardized statistical criteria. Empirically found that the efficiency of the technology as mediation procedures Public Administration correlated as combatants with the characteristics (individual, social) and professional characteristics of public official involved in the mediation.

Note that the issues of effective communication, communicative competence of public administration, including use of social and psychological interaction interactive technologies (mediation) is an important and significant factor in social protection of ATO's combatants. In this context, there is need for purposeful formation of certain skills of public servants able to adequately respond to conflict situations in cooperation with social groups. Therefore, the Department of Public Management of NAPA under the President of Ukraine in collaboration with Hamburg University and other partners to develop scientific and practical research on communication issues, introduce projects to develop technologies dialogue interactions in the system of public administration. Note that this research themes consistent with the context of establishing the institute of mediation in Ukraine, and why are devoted to our further scientific research and study.

\section{References}

International Statistical Classification of Diseases and Related Health Problems 10th Revision (ICD-10) - WHO Version for, 2016, http://apps.who.int/classifications/icd10/ browse/2016/en [28.01.2017].

Sexual Abuse Task Force and Research \& Practice Core, 2004, National Center for Child Traumatic Stress, https://goo.gl/ cs9Yav [28.01.2017].

Ursano R.J., Bell C., Eth S., Friedman M., Norwood A., Pfefferbaum B., Pynoos R.S., Zatzick D.F., Benedek D.M., 2010, Practice guideline for the treatment of patients with acute stress disorder and posttraumatic stress disorder, Work group on ASD and PTSD, American Psychiatric Association, http://goo.gl/5pR4ek [28.01.2017].

Білинська М.М., 2013, Стратегія державної кадрової політики України: чілі та шляхи реалізації, 2013, НАДУ, Київ.

Бурдье П., 2007, Социология сочиального пространства, Институт экспериментальной социологии, Санкт Питербург, Алетейя, Москва.

Гай-Нижник П.П., 2017, Росія проти України (1990-2016 рр.): від політики шантажу і примусу до війни на поглинання та спроби знищення, МП Леся, Київ, http:// hai-nyzhnyk.in.ua/doc/2017doc.rosiya-proty-ukrainy.php [28.01.2017].

Головатий М.Ф., 2005, Соціальна політика і сочіальна робота, МАУП, Київ.

Горбулін В.П., 2016, Тези до другої річниці російської агресії проти України (20 лютого 2016 р.), http://uacrisis.org/ ua/40347-gorbulin-tezy [28.01.2017].

Редлих А., Миронов Е., 2009, Модерация конфрликта в организачиях, Речь, Санкт Питербург. 
Решетніченко А.В., Кірєєва О.Б., Голубчик Г.Д., Хміль Т.В., Брус Т.М., Шевченко С.О., Каховська О.В., Романенко К.М., Кринична І.П., Бессараб Є.І., Попович Ю.Д., Ковальова Д.В., Киричук Ю.Л., Лисенко В.В., Поспєхова Г.М., Черкасова А.С., Сотнікова І.В., 2012, Базові засади соціального розвитку як сфери публічного адміністрування, НАДУ, Київ, https://goo.gl/Q9Abdu [28.01.2017].

Скуратівський В., Палій О., Лібанова Е., 2007, Сочіальна політика, Вид-во УАДУ, Київ. 